\title{
Os discursos sobre as raças e a ciência
}

\section{MICHEL PATY}

\section{De novo, a besta imunda ronda por aqui}

$\mathrm{O}$ RECRUDESCIMENTO recente de discursos políticos abertamente racistas é um sintoma inquietante da fragilidade de nossas sociedades e um lembrete de que retrocessos são sempre possíveis. Após a mais sinistra experiência que a humanidade conheceu nessa ordem para os tempos modernos, o genocídio programado e realizado pela Alemanha nazista e por seus colaboradores contra os judeus e outros grupos humanos rebaixados à categoria de subhomens, poder-se-ia pensar que pelo menos uma lição do horror tivesse sido retida, que o sinal de alarme tivesse sido ativado para as conseqüências últimas a que conduz a lógica da segregação e do racismo.

A humanidade, enfim despertada, parecia ter decidido romper de uma vez por todas com essas premissas: os povos pareciam ter-se colocado como dever a extirpação desse câncer, banindo as segregações racistas da organização de suas sociedades e de suas leis. Não se pode subestimar a esse propósito a significação das lutas, longas e dolorosas, pelos direitos civis nos Estados Unidos, contra o apartheid na África do Sul... Não se trata de que a igualdade tenha de agora em diante verdadeiramente entrado nos fatos e que o racismo tenha desaparecido como por encanto nesses países - nem em outros. As realidades sociais, os comportamentos e as mentalidades sempre demoram a se transformar, e a erradicação definitiva do pensamento desigualitário, pode-se imaginar, seria uma obra de grande fôlego. Pelo menos tínhamos tomado o caminho, que esperávamos fosse irreversível. O racismo tornou-se vergonhoso e não ousava mais se expor à luz do dia. Mesmo em situações agitadas (como, na França, durante a guerra da Algéria), os comportamentos racistas não ousavam se expor abertamente, nem se cobrir de justificações teóricas (e os pensadores da desigualdade racial, pois que sempre os houve, não apareciam mais na cena política).

A besta imunda ( 1 ) reapareceu, alhures, em regiões do globo desestabilizadas política e economicamente, sob a forma de lutas étnicas, na ex-Iugoslávia, na África da região dos Grandes Lagos, que brotam ainda de modo endêmico, ou não, em outros países: desejaríamos atribuí-las a antigas oposições arcaicas, produzidas pelas circunstâncias, anacrônicas e de qualquer modo distantes... Mas não tão distantes: a besta retornou nestes últimos tempos a rondar por aqui. Descobrimos seu germe até mesmo entre nós - não apenas à nossa porta, mas no próprio coração de nosso país - onde se apela, do modo mais oficial do mundo, para a segregação e a 
rejeição do outro, do estrangeiro. Essa rejeição está consignada na própria lei (no sentido jurídico) - lei Pasqua, lei Debré -, em nome de razões políticas superiores que seriam ditadas pela lei inexorável (num sentido supostamente científico) da economia, pela (justa) dissuasão de uma imigração clandestina. Mas ao invés de controlar tal imigração, a lei ao contrário a reforça ao assimilar clandestinos e nãoclandestinos, levando os não-clandestinos a tornarem-se clandestinos, e acaba de fato criando situações desumanas (como a separação de famílias), inextrincáveis e gratuitas face às razões invocadas. A verdadeira razão, inconfessável, da elaboração dessas leis foi a de captar o eleitorado do partido xenófobo.

Tais leis trazem um pensamento de segregação - anteriormente inadmissível na democracia deste país - amplificado muito freqüentemente pelo zelo intempestivo de funcionários medíocres, subalternos ou não, receptivos aos discursos da desigualdade que thes parecem concordantes com aqueles regulamentos que eles aplicam, indo além dos próprios textos. Essas leis, em verdade, estão contaminadas desde o interior pelo vírus xenófobo e racista, que elas nutrem e amplificam. As ideologias que trazem o vírus dessa peste não têm necessidade, para ganhar terreno, da ascensão ao poder do partido que a ostenta. Outros se encarregam disso por ele, enquanto pretendem evitá-lo, e põem sem perceber o verme na fruta.

\section{O discurso sobre as raças e o racismo}

É nesse contexto e nesse clima que se assiste a uma retomada de discursos ideológicos sobre as raças, desta vez no plano político. "As raças são desiguais, esta é a evidência", proclamou o chefe da Frente Nacional e os eleitos de seu partido vão além na cantilena, para ver onde isso vai dar e até que ponto seria tolerado o intolerável. As reações foram as mais diversas, não sendo forçosamente melhores aquelas que se exprimiram por meio de palavras, mas antes aquelas que manifestaram mediante sua mobilização ativa (2) a rejeição absoluta e global das teses propostas - as teses acima e aquelas mais ordinárias que as acompanham -, como daqueles que as proferem e aquela das contaminações de aparências mais benignas mas também perniciosas. O não ao partido do ódio, a seus chefes, a seus homens, assim como a seus conselheiros e a seus cúmplices, voluntários ou não, não pode ser senão global e deve ser exercercido inicialmente pela vigilância da ação.

Assim também não é ao partido do ódio e a seus êmulos que estão destinadas as considerações que se seguem. Aqueles não escutam, encerrados na fabricação paranóica de suas próprias verdades fechadas. Eles proferem em praça pública o que, seja dito de passagem, não tem estritamente nada a ver com uma atitude política, pois toda idéia de diálogo - essencial na democracia - está ausente. Não se trata, no caso, de fazer política, mas de representar o falso profeta que enuncia as evidências falsas. Enganar-se aqui de qualificação é uma falta de inteligência grave. Sofismas irresponsáveis têm sido enunciados a esse propósito com uma desenvoltura surpreendente (3). Os intelectuais de profissão não estão dispensados do exercício do bom senso quando se espera deles, ao contrário, reflexões confiáveis sobre seu domínio de competência. 
A verdade é aqui uma noção de primeira importância, e não desejamos nos livrar dela mesmo sabendo que nossas verdades são em geral relativas. Existem aquelas às quais se dá mais valor do que à própria vida, talvez precisamente porque muitos pagaram por elas, voluntariamente ou não, com o preço de suas vidas. Certas leviandades não estão verdadeiramente à altura do jogo. Aliás, eu teria a tendência a pensar que elas contribuem, apesar de seu caráter derrisório, ao deslizamento, ao qual, parece, assistimos, em direção à aceitação de discursos inaceitáveis - lançados justamente para ver o que acontece. E vemos.

A afirmação da desigualdade das raças é inaceitável de vários modos, e suscitou contra si comentários variados que não foram desprovidos de paixão. Alguns levantam antes de tudo uma questão relativa a um conhecimento e exigem da ciência a demonstração da inutilidade dos propósitos racistas, estabelecendo cientificamente a inexistência de raças significativamente distintas na espécie humana. A lei deveria, segundo eles, sancionar esse conhecimento objetivo, biológico. A dimensão política da questão é então apagada, o que evita o levantamento de outros problemas. Outros rejeitam esse naturalismo da igualdade dos seres humanos, decidindo que a questão é de natureza totalmente política, com a exclusão de toda consideração natural ou de caráter científico. Alguns destes últimos estimam que uma sociedade tem o direito, afinal de contas, de escolher ou não a exclusão e de ser ou não racista.

Curiosamente, nos debates em que se confrontam os defensores dessas duas análises contra as teses desigualitárias, é freqüente ver a paixão apossar-se de uns contra as razões dos outros, quando ela deveria torná-los antes de tudo contrários ao bardo do desigualitarismo e do racismo. Seria essencial, porém, mantendo a razão, não se enganar de adversário e de inimigo: o contrário seria uma estranha perversão dos valores que daria satisfação ao "homem do ódio" (Le Pen, la haine).

Entre essas duas posições nítidas, extremamente esquemáticas, é possível raciocinar diferentemente, preservando a dimensão política, sem negar as razões objetivas para condenar o racismo, razões que estão primeiramente ligadas à escotha de valores, mas que, sem por isso cair no naturalismo, não podem ignorar o aporte dos conhecimentos científicos.

A afirmação da desigualdade das raças põe em primeiro lugar a questão de seu conteúdo. Ela tem sentido? Ela é racista? À primeira questão, deve-se responder que não: a afirmação as raças são desiguais não tem qualquer sentido. À segun$\mathrm{da}$, deve-se responder ao meu ver que sim, pois ainda que seja objetivamente desprovida de sentido, a afirmação denota uma intenção desigualitária baseada em um pensamento racista, e pode-se até mesmo afirmar que o pensamento desigualitário confunde-se com o racismo e que os dois são condenáveis. Depois de estabelecido esses dois resultados, como procurarei fazer, restará saber o que se deve responder ao discurso desigualitário e racista: deve-se fazer uma lei em nome de uma verdade que a afirmação transgrediria, e cujas exigências não estariam presentes na lei atual? Mas sabe-se que as leis sobre os delitos de opinião devem ser manejadas com pre- 
caução, por haver sempre a possibilidade de seus efeitos perversos. Ou será suficiente opor à falsa novidade e à propaganda perniciosa o conjunto de possibilidades de impedir de ser nocivo, que a sociedade dispõe, tanto com suas organizações como com suas leis? Terminarei com esta questão, fundamental para a vida na democracia, para a proteção das idéias de democracia e para a própria defesa da democracia.

\section{Uma questão desprovida de sentido e apesar disso orientada}

Os comentários contrários ao discurso sobre a desigualdade das raças sublinharam a incoerência de uma tal expressão, que mescla duas considerações heterogêneas. Essa incoerência equivale a uma ausência de sentido.

Uma raça relaciona-se a um estado de fato, verdadeiro ou falso, relativo à natureza. Tanto segundo a psicologia e a cultura quanto segundo a biologia, cada ser humano é um indivíduo diferente dos demais. Semelhanças relativas a certas características permitem reagrupá-los em famílias: tais são as raças que se supõe serem entidades significativas do ponto de vista biológico e, portanto, objetos da ciência. Acerca de um tal objeto pode-se constatar qualidades, semelhanças, a saber, identidades, diferenças, variedades e variações, mas não igualdades ou desigualdades. A igualdade e a desigualdade que comparecem na ciência não são senão aquelas das grandezas suscetíveis de uma determinação numérica. Não concernem estritamente falando senão às matemáticas (igualdade de números, de expressões simbólicas, de figuras geométricas) e às ciências físicas e químicas, cujas grandezas são expressas com o auxílio da matemática (temperatura, velocidade, comprimento de onda etc.). Quando as ciências biológicas ou as ciências sociais utilizam as matemáticas, elas o fazem sempre por meio de convenções precisas, que não recobrem a totalidade dos objetos estudados, por exemplo, na utilização de estatísticas. A capacidade craniana ou o ângulo facial, a altura, o peso e, mesmo, o número de cromossomas e a natureza dos genes não fazem um homem e, portanto, a fortiori uma raça.

Quanto ao demasiadamente famoso QI (coeficiente de inteligência), ele não fornece qualquer medida da inteligência no sentido biológico como se pretendeu por vezes fazer acreditar. Proposto por Alfred Binet no início do século, com o fim limitado de testar as aptidões dos alunos para o estudo, permanece com toda a evidência como um teste unicamente cultural e constitui um índice de integração e aptidão social. Invocá-lo como uma variável significativa da inteligência humana, ou seja, como uma definição biológica do homem, é um erro de método científico cometido de maneira deliberada por razões ideológicas e, portanto, um embuste. Toda uma literatura supostamente científica renasce periodicamente sobre essa interpretação abusiva do QI. Há 15 anos, por exemplo, com uma série de obras sobre a desigualdade humana muito estimadas pela Nova Direita e, muito recentemente em tradução francesa, o grosso volume com título esotérico - sem dúvida para torná-lo mais cientificamente (novo) rico-, de Charles Murray e Richard Herrnstein, 
A curva de Bell (1994). Os autores demonstram nessa obra a origem hereditária das desigualdades sociais e, portanto, a inutilidade de promover as minorias étnicas (principalmente negras) socialmente desfavorecidas.

A ignorância ou o erro poderiam até ser permitidos, mas não a vontade de enganar. Essa é a diferença entre os primeiros antropólogos dos séculos XVIII e XIX e os socio-biólogos de hoje: os primeiros poderiam acreditar de boa fé em sua ciência ainda balbuciante, sem ter consciência de que não faziam mais que hipostasiar num pretenso conhecimento científico os prejuízos raciais, ou seja, racistas, da sociedade de seu tempo; mas os conhecimentos adquiridos hoje não permitem um tal retorno e o desigualitarismo científico é uma impostura.

Além disso, não existe definição de inteligência no sentido biológico. A inteligência é uma noção complexa, mais intuitiva que precisa, que intervém em vários níveis da realidade. Os biólogos preferem falar de aptidões, especificando-as, mas estas resultam em si mesmas de interações complexas no nível dos neurônios, em que as aquisições da aprendizagem e da cultura jogam um papel fundamental.

A outra consideração (desigualdade ou igualdade) concerne um juízo de valor em um sentido que não corresponde a nada de inscrito na natureza, mas depende de uma decisão de ordem moral. A axiologia não é matemática, os valores morais não são números, nem autorizam a dizer que um certo ser é igual ou comparável (no sentido precedente) a um outro. O qualificativo de igualdade ou desigualdade aplicado ao homem - assim como à maior parte das espécies biológicas jamais poderá ser aplicado como resultado de um conhecimento científico. Mas a igualdade - no sentido da palavra que orna as fachadas de nossos prédios públicos -, que é político e concerne à igualdade de direitos e de deveres, é uma opção, uma decisão, uma escolha.

A Declaração universal dos direitos do homem de 1948 afirma, em seu preâmbulo, que "o reconhecimento da dignidade inerente a todos os membros da família humana e de seus direitos iguais e inalienáveis constitui o fundamento da liberdade, da justiça e da paz no mundo". Este é o único sentido que se pode atribuir, concernente aos homens e aos grupos humanos, à noção de igualdade. Falar em seu lugar de desigualdade, não pode significar que os homens seriam desiguais por natureza, o que, como vimos, não tem sentido, mas que a igualdade de direitos lhes é recusada, por decisão, por decreto, ou seja, se preferirmos, o direito à igualdade, que a Declaração universal lhes reconhece. Eis porque a associação dos termos raças e desiguais em uma expressão como as raças são desiguais não pode mais que reenviar, da parte daquele que a pronuncia, a uma decisão unilateral sobre os outros seres humanos, contra sua dignidade e seus direitos. Subjacente a ela encontramos, em verdade, sem ter necessidade de procurar muito longe, o racismo natural e (pseudo) cientifico, do qual há bem pouco tempo os nazistas se fizeram os arautos e, além deles, as ideologias desigualitárias daquele gênero defendido pelo conde Arthur de Gobineau, autor de um Ensaio sobre a desigualdade das raças humanas (Paris, 1853). Essas ideologias tiveram uma descendência científica com 
o eugenismo e o darwinismo social, que queriam se fazer passar por ciências quando não repousavam senão sobre prejuízos viscerais ou sociais colocados na forma de teoria. Essas teorias serviram de justificação biológica para práticas sociais altamente desigualitárias como a escravidão, a exploração colonial e toda espécie de segregação e de servidão, até que o sistema se lança no turbilhão mortal de sua lógica tornada louca. Sempre se encontraram, como lembra André Pichot, biólogos - eminentes ou não - para fornecer a quem lhes pediam tais justificações para suas classificações raciais (4). Encontram-se outros hoje em dia para o fazer, outros que teorizam sobre o QI, que propõem uma explicação geral dos caracteres pelos genes (pangenetismo). A socio-biologia atual, que pretende se apoiar na genética molecular, explicando as aptidões intelectuais ou artísticas dos indivíduos pela presença de genes específicos, é um dos rebentos mais recentes da linhagem.

Tais antecedentes da afirmação de uma desigualdade entre os homens ou entre as raças deixam freqüentemente ver que não se pode dar uma proeminência nessa questão àquilo que se toma, em uma época determinada, em uma sociedade determinada, como ciência. Guardamos legitimamente a esperança de que sob as vestes da ciência se esconde muito de ideologia sobre essas questões, mesmo hoje em dia, e que essa suposta ciência, sem dúvida, se encontra ainda marcada por fantasmas. Felizmente, os valores estão imunizados a esse respeito, pois não são, como vimos, objetos da natureza. A ciência jamais ditará, portanto, legitimamente escolhas nessa questão, a não ser por abuso. Nem por isso deixará ela de ter algo a dizer, e a questão de decretar ou não relações de igualdade entre as raças não seria então concernente senão a uma decisão política? Isto seria abandonar toda possibilidade de se referir aos conhecimentos científicos na mão daqueles que, pouco escrupulosos sobre os métodos, escolheram utilizá-los para o pior: daqueles que jamais estão inclinados a colocar em dúvida seus resultados em nome de uma exigência (de verdade) mais alta que seus prejuízos, ou daqueles que são grosseiramente falsificadores e fabricantes de pseudo-verdades para seu próprio uso.

\section{Raças e racismo}

Empregar o termo raça não implica a priori que se seja racista. Sua acepção há muito era vaga: significava a princípio aqueles aos quais se relaciona por laços de sangue, a linhagem, a família no sentido de enraizamento à terra, à cultura. Dizia-se até bem recentemente raça para etnia ou povo ("A nação na qual tantas raças vieram a fundir-se", escrevia Paul Valéry a propósito da França). Servia também para designar, no sentido em que se entende sobretudo hoje em dia, os grupos humanos diferenciados segundo caracteres que nunca foram puramente físicos a não ser nas classificações dos zoologistas.

A antropologia moderna dissociou a raça - que se funda em caracteres físicos - e a etnia - caracterizada pela cultura - (5); e ainda distintas das duas, a nação ou o Estado, que concerne a uma organização política. As prevenções dos grupos humanos entre si no curso da História mesclaram indistintamente raça, etnia, nação para designar o outro, o estrangeiro, o bárbaro, aquele que não é de nosso povo, 
o qual se denominava freqüentemente, pela diversidade das línguas, simplesmente os homens...

Mas, ao mesmo tempo em que a idéia de humanidade e de unidade do gênero humano se impunha pouco a pouco na Europa por meio de efeito inverso, sobre outro terreno, mais frio e calculado, os naturalistas e os antropólogos incluíam o homem entre as espécies biológicas e procuravam para ele critérios de classificação análogos aos das espécies animais. A noção de raça, sem conotação de hierarquia ou de valor, não fazia senão exprimir como uma constatação a variedade dos caracteres humanos, anatômicos, fisiológicos, psicológicos, patológicos, que podiam ser reagrupados e atribuídos a traços hereditários comuns a grupos, chamados raças e supostos de corresponderem aproximadamente às subespécies dos zoólogos e às variedades dos botânicos (6). Esses caracteres foram colocados com relação às distribuições geográficas das populações e tentativas de explicações naturalistas, em termos físico-químicos, foram propostas (já com Buffon e Cuvier). Nesse estágio da ciência da antropologia física, a diversificação da espécie humana em raças não era necessariamente transcrita em termos de desigualdades ou de hierarquias. Mas, por outro lado, os prejuízos contra o outro, o diferente, o estrangeiro, latentes em todos os povos, exacerbados pelas conquistas e pelo colonialismo, autorizaram a escravidão, o direito de vida e morte, até mesmo o genocídio, sobre as populações dominadas e desprezadas. As ciências ainda balbuciantes da vida e da sociedade formaram-se nesse contexto. A diversidade e a classificação das raças humanas, concebidas por analogia às espécies animais, mas estabelecidas sobre métodos muito mais incertos, foram freqüentemente utilizadas como um fundamento racional suscetível de justificar a exploração dos seres humanos apesar de estes terem sido de outro lado reconhecidos como iguais em dignidade (ver adiante). Mas o deslizamento da questão das raças para um problema de desigualdade não ocorreu senão tardiamente, quando o darwinismo social pretendeu hierarquizar os componentes da espécie humana em termos de raças mais ou menos evoluídas.

Essa esquematização da preocupação biológica com as raças condensou-se, portanto, ao final do século XIX, ao mesmo tempo que outras radicalizações teóricas fundadas em ideologias nacionalistas e etnocêntricas, por exemplo, na lingüística, à época dos imperialismos europeus. As teorias supostamente científicas sobre as raças não faziam mais que refletir as ideologias da época, suscitadas pelas necessidades econômicas e políticas das grandes potências no apogeu do colonialismo. Isso torna relativo um certo saber cientificico. Trata-se agora de conhecer a continuação, quando essas ciências alcançaram um maior rigor. $\mathrm{O}$ homem atual, homo sapiens sapiens, segundo os dados da paleontologia, originou-se de grupos ou espécies mais antigas, menos evoluidas segundo a perspectiva da evolução das espécies: homo sapiens, homo habilis, homo erectus etc. (7). Todos os homens atuais pertencem à espécie homo sapiens sapiens, que nós chamamos, com efeito, a raça humana (atual), a qual compreende as variedades que conhecemos, objeto de modificações, de mestiçagem, de misturas de caracteres morfológicos e genéticos (combinados com as interações culturais), e se distribuem de maneira complexa segundo as etnias e as línguas. 
Sabemos agora que essas distribuições escapam à possibilidade de toda classificação estrita em termos de raças. Os estudos sobre as distâncias biológicas relativos a certas propriedades hereditárias (grupos sangüíneos etc.) entre diversas populações tomadas duas a duas mostraram não ser possível encontrar, por meio de correlações significativas, traços invariantes que corresponderiam a raças definidas, e fazem assim aparecer a noção de raça como uma construção artificial. Além disso, com a mobilidade das populações, as raças não são mais fixas, mas se mostram como realidades dinâmicas que se transformam.

Por outro lado, as tentativas de diferenciações antropométricas, caras à classificação das raças e ao eugenismo, desapareceram da ciência moderna após a Segunda Guerra Mundial, não por razões ligadas aos acontecimentos políticos, mas pura e simplesmente em virtude dos progressos dos conhecimentos em genética que tornaram esse problema obsoleto, ultrapassado e estranho à ciência.

A morfologia e a hereditariedade estão hoje relacionadas às propriedades genéticas. O conhecimento dos genes com relação a certos caracteres morfológicos permite precisar as variações entre os grupos humanos por meio do estudo das distâncias genéticas. Ora, estas últimas não fazem aparecer correlações significativas. As diferenciações genéticas (8) nos grupos humanos são incomparavelmente mais fracas que aquelas constatadas nas subespécies animais, o que indica não existirem subespécies na espécie humana (9). De maneira geral, os dados da taxonomia e da genética mostram que a noção de raça no sentido usualmente admitido não tem significação biológica profunda (em particular, a cor da pele é um caráter bastante superficial, cuja significação genética é praticamente nula).

A genética molecular permitiu portanto modificar substancialmente a questão das raças. Em um encontro de geneticistas lembrava-se, no outono de 1996, não se conhecer para os humanos marca genética que caracterizaria uma população particular por exclusão das outras: "Sejam elas concernentes aos grupos sangüíneos, aos grupos de histocompatibilidade ou aos fatores enzimáticos, as análises efetuadas um pouco por todo o mundo desde há meio século demonstraram que a grande maioria dos caracteres genéticos da espécie humana estão presentes em quase a totalidade das populações" (10). No mesmo encontro declarava-se que, do ponto de vista biológico, não existe senão uma única raça humana, que a raça, no concernente ao homem, é portanto um conceito falso, e que pretender fundamentar um racismo sobre a ciência é uma impostura.

Tais resultados científicos atuais não significam que, se existissem raças, resultaria uma hierarquia de raças e se deveria então ser naturalmente racista. $\mathrm{O}$ racismo não está inscrito na natureza, existam ou não raças: é uma decisão humana, que escapa à esfera da biologia e se mantém no âmbito dos valores (sendo um valor negativo). A palavra racismo significa "teoria da hierarquia das raças, que conclui pela necessidade de preservar a raça dita superior de todo cruzamento e que tem o direito de dominar as outras", segundo a definição do Dicionário Petit Robert, que indica a entrada dessa palavra na língua francesa: 1930, apresentando Mein Kampf 
como o "evangelho" (11) do racismo, com o seguinte detalhamento: "o racismo não tem nenhuma base científica" (12). Acentuemos ainda: ele não tem nenhuma, nem teria mesmo quando existissem raças diferentes. Se chegarmos um dia a entrar em contato com seres pensantes e conscientes vindos de outros lugares do cosmo e que sejam muito diferentes de nós morfológica e geneticamente, seremos certamente obrigados a adotar com relação a eles uma cláusula de respeito e de igualdade, semelhante àquela que reconhecemos para a humanidade. Nossa noção de humanidade deveria então ser estendida àquela do conjunto dos seres pensantes providos de razão e consciência, caracteres que fazem nossa dignidade própria.

A situação atual da humanidade sobre a Terra, muito homogênea em razão das trocas estreitas que tiveram lugar ao longo dos milênios entre as diversas populações, aparecer-nos-ia então como uma particularidade local. É possível conceber em abstrato uma humanidade mais ampla e diversificada, que nos obrigaria da mesma maneira. Nossa situação presente é mais fácil - e existem aqueles que não se apercebem disso! Que massacres alguns não se sentirão prestes a cometer contra seres que embora iguais (porque pensantes e conscientes), seriam verdadeiramente diferentes! Mas deixemos essas especulações, para retornar a nossa situação presente e real.

\section{A sabedoria humana e a igualdade na diferença}

A sabedoria humana não esperou a ciência dos antropólogos e suas classificações (variáveis segundo as épocas e os autores, freqüentemente contraditórias e sempre revisáveis) para que o semelhante reconheça seu semelhante e para conceber a igualdade fundamental dos seres humanos, isto é, sua igual dignidade. A noção de humanidade em sua totalidade não foi reconhecida senão ao fim de uma longa história, fazendo desvanecer as barreiras entre tribos, religiões e impérios. Que eles se tenham visto filhos de Deus e portanto irmãos, ou descoberto semelhantes no próprio curso de suas lutas entre si, ou se aproximado pelo acesso à cultura, ou tenham compreendido, com os filósofos, que os homens, de todas as latitudes e dos países mais distantes, estão dotados de razão - de Aristóteles a Descartes - ou são capazes de rir - com Montaigne e Rabelais - assembléias de homens enunciaram em seu próprio nome e em nome dos outros a igualdade fundamental dos seres humanos, que subentende a noção de humanidade.

Eles a entendiam qualquer que fosse o que se chamava então suas raças, e significavam que, nas diferenças constatadas (sexo, cor da pele, forma da cabeça, língua, hábitos sociais, crenças), nenhuma maculava a igual pertinência a essa qualidade, a essa igualdade definida e escolhida a partir desde então como um valor. Essa escolha baseava-se em uma consciência da experiência humana e também em uma idéia humana da natureza (característica da época): esses seres proclamados iguais possuem estruturas físicas iguais, estão dotados de palavra, de pensamento e de consciência - ou reflexividade do pensamento -, com esta última característica distinguindo-os dos animais superiores - aos quais atribuímos hoje em dia uma certa forma de pensamento, mas não a consciência (13). 
É esta decisão que se exprime na afirmação magnífica, simples e definitiva, da Declaração dos direitos do homem e do cidadão da Revolução Francesa de 1789, em seu primeiro artigo: "Todos os homens nascem livres e iguais por direito" (14). As desigualdades não são senão relativas ao interesse social $\mathrm{e}$, em todo caso, não estão inscritas na natureza ou na fatalidade. A Declaração universal dos direitos do homem, adotada pela Assembléia Geral da Organização das Nações Unidas em 10 de dezembro de 1948, a retoma, igualmente em seu primeiro artigo, com um acréscimo que torna explícito o reconhecimento da dignidade humana, baseando-a na razão e na consciência: "Todos os seres humanos nascem livres e iguais na dignidade e no direito. Eles estão dotados de razão e de consciência e devem agir uns para com os outros com um espírito de fraternidade".

Dizer que os homens são desiguais em razão de suas raças é antes de tudo, do ponto de vista político, recusar este artigo fundamental da primeira Constituição da República (francesa) - retomado em sua essência pela Declaração universal dos direitos do homem de 1948, e que continua figurando na atual Constituição da República francesa. Recusar o que pertence daqui por diante e definitivamente às concepções comuns da humanidade, estabelecendo-a na consciência dela mesma, resulta, estritamente falando, em banir-se da humanidade. Esta questão de natureza política - a igualdade - é hoje o objeto de uma aquisição pertencente à prática social e ao direito, que não se quer mais admitir ser posta em questão, e não mais suscetível de ser o objeto de uma decisão política que estaria sujeita ao sabor das circunstâncias e que a modificaria. Ao menos devemos lutar para tanto, pois isso dá sentido ao nosso destino. Nossa sociedade e nossa civilização, a não ser que se destruam e se neguem, estão fundadas na idéia, constituída e reconhecida por elas, de os homens, diferentes por natureza ou por cultura, serem iguais em essência, isto é, em seus direitos e em seus deveres fundamentais. A recusa dessa declaração de pertencer à humanidade abre a possibilidade dos crimes contra a humanidade, como o ensina a história recente e presente.

Trata-se de uma decisão de alcance político fundada sobre uma escolha axiológica, uma escolha de valores. Essa escolha se apoia em um saber que está profundamente enraizado na experiência humana e na história de todos os povos. Ela corresponde ao grito elementar da sobrevivência humana. Em seu livro sobre a experiência dos campos de extermínio, A espécie humana (Gallimard, Paris, 1947), Robert Antelme relata um fato, que foi sem dúvida único na história da humanidade: os condenados ao extermínio tinham "sido levados a exprimir como única reivindicação um sentimento de pertencer à espécie". Eis o que se deveria fazer valer para os partidários da desigualdade das raças, se eles pudessem escutar - e observar - esse grito de pertencer que foi recusado às vítimas do extermínio: "Vede ao que conduz a afirmação de uma desigualdade e de uma hierarquia das raças". Não apenas o grito em sentido próprio, mas também o olhar, que é um outro grito de toda humanidade. É ele que seria necessário em primeiro lugar mostrar aos partidários da desigualdade das raças e do racismo: os olhos das crianças dos povos de todo o mundo que os olham, os interrogam, exigindo-lhes que prestem contas. 
A abertura, o espanto, ou a aflição nesses olhos bem abertos, que os sondariam até o fundo deles mesmos se soubessem vê-los, esses olhares que exprimem da maneira mais nua, desprovida de discurso e de artifícios, a interpelação que nos invade. Por todos os tempos, desde que a humanidade existe, é pela interpelação de um olhar que o homem se reconhece, que ele se reconhece a si próprio em sua humanidade, em sua dignidade inalienável. A troca pelos olhares exprime, antes de se estabelecer por meio das palavras, a irrefutável presença das consciências e sua igualdade fundadora - sua fraternidade -, de igual para igual.

O olhar, desde a criança até o velho - esse grito silencioso, imediato, evidência de nossa humanidade.

\section{O direito, os valores e a ciência}

Resta-nos agora saber o que devemos fazer com os proferimentos públicos, como aqueles acerca da desigualdade das raças, em si mesmos desprovidos de sentido, mas condenáveis porque exprimem uma postura racista. Enquanto eles não se refiram a um objeto preciso e não ponham em causa indivíduo algum ou grupo particular, eles não se prestam a medidas diretas, e não constituem mais que o enunciado de uma opinião. A esse respeito, as leis atuais podem condenar delitos graves de opinião como a incitação à violência, ao ódio etc. É tarefa dos juristas saber se a expressão incriminada incorre no que está previsto pela lei. Essa opinião é perniciosa, pois ela quer fazer crer que o racismo (contido no enunciado da desigualdade, que implica uma hierarquia, e portanto uma diferença de direitos) estaria inscrito no conhecimento. Sob este aspecto, ela constitui uma contraverdade.

A lei não condena de maneira sistemática a crença em contraverdades, entendidas seja segundo o senso comum seja segundo o senso científico, e isso é de qualquer modo preferível, pois sabemos que o senso comum é modificável, e não estamos sempre absolutamente certos de nossas verdades científicas (aliás sempre sujeitas a aperfeiçoamentos). Nenhum tribunal condenaria um indivíduo que afirmasse que a Terra é plana, embora saibamos (irreversivelmente nesse caso) que uma tal asserção é falsa. A opinião de um indivíduo não poderia ser objeto de condenação enquanto for expressão unicamente de foro íntimo e permanecer privada. Deve-se tolerar a ignorância, a imbecilidade e, mesmo, a malevolência, enquanto elas se limitam à esfera do indivíduo. Mas a partir do momento em que saem dessa esfera, e que correm o risco de causar efeitos sobre outros indivíduos ou sobre a sociedade, põe-se o problema da liberdade ou da repressão.

Um indivíduo ou um grupo que se proponham a ensinar publicamente contraverdades evidentes do gênero a Terra é plana (contraverdade sobre a natureza), ou não houve exterminação nos campos de concentração nazistas (contraverdade sobre os fatos históricos) ou, ainda, as raças são desiguais, tal raça é inferior a uma outra (negação de nossos valores fundamentais e contraverdade sobre os conhecimentos comuns e científicos), constituiriam um perigo para a sociedade. A sociedade deveria então defender-se, e ela pode defender-se em diversos níveis. 
Em primeiro lugar, no nível da educação e do ensino, uma das primeiras missões de uma sociedade: a noção de verdade, temperada certamente pelo espírito crítico que a escola tem igualmente a missão de ensinar, deve imperativamente permanecer como um valor fundamental de referência. A escola e a universidade (pública ou privada) devem impedir o ensino de contraverdades flagrantes, em particular se elas são socialmente perigosas e, em geral, o fazem. Uma sociedade deve defender-se desses perigos em nível de suas instituições (o que é óbvio) (15), mas também de seus agentes e de seus representantes. Um funcionário de prefeitura ou um policial que afirmasse teses racistas deveria ser demitido de suas funções por falta grave - e isto deveria estar inscrito na lei relativa à função pública.

Em resumo, o ensino, a difusão ou a propaganda pública de contraverdades manifestas com o fim de perverter (16), ou de contrariar as escolhas de valores fundamentais admitidos por uma sociedade e que assegurem sua coesão, fornecendo sua significação, não podem ser admitidas e devem ser impedidas e eventualmente condenadas. Deve-se entretanto considerar que a liberdade de opinião constitui uma das proteções fundamentais dos cidadãos em uma sociedade, e que a lei não pode restringi-la demasiadamente sem risco para a democracia. Não é pois desejável deixar aos governantes e aos políticos cozinhar apressadamente, devido a uma conjuntura particular, uma modificação dessa lei, cujas exigências poderiam conduzir a efeitos perversos mais graves que as carências inicialmente visadas. Mas seria o papel do legislador pensar a longo prazo, com serenidade, independentemente da atualidade imediata, à inscrição no direito dos limites da tolerância que não devem ser ultrapassados para a defesa e a preservação dos valores fundamentais de nossa sociedade (17).

Notas

1 “Ainda é fecundo, o ventre da besta imunda" (Bertold Brecht).

2 Particularmente aquela de 29 de março de $1996 \mathrm{em}$ Strasbourg contra a Frente Nacional.

3 Bruno Latour, em uma coluna livre do Le Monde de 4 de outubro de 1996 intitulada Um novo delito de opinião: fazer política, opõe-se, o que é perfeitamente seu direito, à idéia de um projeto de lei para condenar tais declarações em razão de sua falsidade. Mas certos elementos de sua argumentação não deixam de surpreender. O que faz o sucesso do Sr. Le Pen, escreve, é que "ele não transmite verdades. Ele não transmite nada. Ele exprime", e não se deve confundir "os erros que ele arrota com a verdade muito exata que ele enuncia [a saber, que] a política não é uma sala de aulas" (Sou eu, M.P., que sublinha. Mas se as palavras possuem um sentido, parece-me existir aí algumas contradições. Mas relevemos.) Para B. Latour, o Sr. Le Pen, de quem ele destesta as idéias, empregaria um tom apropriado para idéias falsas, o que seria "escandaloso em sala de aula, mas legítimo em praça pública", não estando em seus propósitos uma reivindicação muito simples: que se trate de questões políticas com os meios políticos”. B. Latour indica-nos ainda que o Sr. Le Pen 
e os franceses que o escutam "servem-se do tema do estrangeiro e da raça para lembrar que a França deve ser composta passo a passo por todos os seus membros; que não existe nada de inelutável em sua composição, de definitivo em seus domínios". Sim, verdadeiramente, "se não existe senão um único homem que sabe fazer política" (o mesmo Sr. Le Pen, segundo B. Latour), pode-se pensar também que o argumento tem valor retroativo, e que tampouco existia, num passado não muito longínquo, só um pensador político, que desejava também escolher os membros com os quais comporia sua nação. O que ele fez dos outros sendo um mero detalhe (isto é uma alusão a outra declaração do mesmo Le Pen, segundo a qual o extermínio de 6 milhões de judeus pelos nazistas era apenas um detalhe da Segunda Guerra Mundial). Pode ser perigoso, mesmo para um sociólogo da ciência tão brilhante e ... inconseqüente, divertir-se com fósforos de verdade que se incendeiam enquanto ele os toma como idéias paradoxais com as quais se brinca como se faz com palavras desprovidas de sentido. O paradoxo das idéias paradoxais é que se pode confundilas com inépcias perigosas.

4 André Pichot, Racisme et biologie, Le Monde, 4 out. 1996, p.14.

5 Ver Henri-V. Vallois, Les races humaines, Que sais je? Presses Universitaires de France, 1944; reedição revisada, 1963.

6 Ibid.

7 Ver especialmente as obras de André Leroi-Gourhan e de Yves Coppens.

8 Relativas às variações dos genes, elas são normalmente tanto maiores quanto mais distantes são as populações.

9 Marcel Blanc, Les races humaines existent-elles? La Recherche, v.13, n. 135, jul./ ago. 1982, p. 930-941.

10 Jean Dausset, François Jacob, Jacques Ruffié, Axel Kahn, André Langaney, Lucas Cavalli-Sforza, Alberto Piazza: Les races: un faux concept, conferência no Museu do Homem, Paris, 10 de out. 1996 (ver a resenha de Catherine Vincent, La race humaine, une et indivisible, Le Monde, 15 dez. 1996, p.18).

11 As aspas se impõem, pois a palavra "evangelho" significa etmologicamente "boa nova".

12 Paul Robert, Dictionnaire alphabétique et analogique de la langue française. Paris, SNL, 1973.

13 Sobre o pensamento nos animais, ver a obra recente de Joëlle Proust, Comment l'esprit vient aux bêtes (Paris, Gallimard, 1997), escrita de um ponto de vista filosófico e muito informada cientificamente.

14 Déclaration des droits de l'homme et du citoyen da Revolução francesa, adotada pela Assembléia Constituinte de 26 de agosto de 1789.

15 Nem sempre é considerado como óbvio, pois vimos recentemente certos homens públicos negarem aos cidadãos a possibilidade de recusar a aplicação de uma lei injusta (a propósito de um projeto de lei de vigilância dos estrangeiros, proposto pelo ministro J.L. Debré e o governo de A. Jupé no início de 1997, e finalmente retirado como efeito de uma manifestação significativa de protesto. Acréscimo do autor para a publicação em português). Cito a excelente análise de Etienne Balibar, Etat d'urgence démocratique, Le Monde, 19 fev. 1997, p. 1, 13. 
16 Como o fazem as seitas.

17 Estas observações concordam com aquelas feitas por Olivier Duhamel, professor de direito, por ocasião de sua conferência proferida em 19 de março de 1997 no âmbito de um ciclo de palestras contra o racismo organizado pela Universidade de Paris I Sorbonne.

RESUMO - NESTE ARTIGO é propõsta uma reflexão suscitada pela atualidade recente na França, onde líderes da extrema direita não hesitaram em fazer declarações públicas abertamente racistas. Nossa sociedade e nossa civilização, a não ser que se destruam e se neguem, estão fundadas na idéia de que os homens, diferentes por natureza ou por cultura, são iguais em sua essência, isto é, em seus direitos e em seus deveres fundamentais. Trata-se de uma decisão de alcance político fundada sobre uma escolha axiológica, uma escolha de valores. Essa escolha se apoia em um saber enraizado na experiência humana e na história dos povos.

ABSTRACT - IN THIS ARTICLE is proposed some reflection provoked by the recent events in France where far-right leaders have not hesitated to make openly racist statements in public. Our society and civilization, unless they are destroyed and denied, are founded on the idea that men, naturally or culturally different, are essentially equal, i. e., equal in their basic rights and duties. This is a decision which has a political significance and is based on a axiological choice, a choice of values. Such choice rests on a knowledge rooted in the experience of mankind and the history of the peoples on the earth.

Michel Paty é diretor de pesquisa do CNRS, França.

Este artigo teve como base a comunicação apresentada no Fórum Racismo e mundialização. Para uma educação do anti-racismo, ADPES, Palácio de Luxemburgo (Senado), Paris, 17 de dezembro de 1996. A versão francesa foi publicada na revista Passages (Paris), n. 83, p. 22-29, maio/jun. 1997.

Tradução de Pablo Rubén Mariconda. O original em francês - Les discours sur les races et la science - encontra-se à disposição do leitor no IEA-USP para eventual consulta. 